\title{
The Belt and Road Initiative Working Towards a Global Vision
}

\author{
LIU Li-juan \\ Tianjin Normal University, Tianjin, China
}

\begin{abstract}
The Belt and Road Initiative is proposed as an international strategy in China. In the eyes of the Chinese people, the Belt and Road Initiative is an international strategy rather than a regional strategy, the goals of which are to coordinate an all-around opening of China to the world and promote further integration of the country into the global economy. So the strategy is talked in almost every field in China. However, Outside of China, the discussion about the Belt and Road initiative does not always provide encouragement and support and typically there are more disputes than agreements. Implementation of Belt and Road is going to reconstruct regional interests and balance powers throughout the world. There are many difficulties in achieving the goal, so China has to realize the true situation in neighboring countries and provide more chances for Non-Governmental Organizations as well as illustrating to the world how China will do in the future.
\end{abstract}

Keywords: The Belt and Road initiative, global vision, suggestion

\section{Introduction}

The Belt and Road Initiative, first proposed by Chinese President Xi Jinping in 2013, is a trade and infrastructure network that includes the Silk Road Economic Belt and the 21st Century Maritime Silk Road. Chinese government, academia, media and most other fields are all involved in the initiative. In China, the initiative was proposed in 2013 and the majority of the planning was done during 2014. From 2015 onward action has been taken to make this initiative a reality.

The Belt and Road run through the continents of Asia, Europe and Africa, connecting the vibrant East Asia economic circle at one end and the developed European economic circle at the other. It also encompasses other countries that all have huge potential for economic development. The Silk Road Economic Belt focuses on bringing together China, Central Asia, Russia and Europe (the Baltic); linking China with the Persian Gulf and the Mediterranean Sea through Central Asia and West Asia; and connecting China with Southeast Asia, South Asia and the Indian Ocean. The 21st-Century Maritime Silk Road is designed to go from China's coast to Europe through the South China Sea and the Indian Ocean in one route, and from China's coast through the South China Sea to the South Pacific in the other. On land, the Initiative will focus on jointly building a new Eurasian Land Bridge and developing China-Mongolia-Russia, China-Central Asia-West Asia and the China-Indochina Peninsula economic corridors. At sea, the Initiative will focus on jointly building smooth, secure and efficient transport routes connecting major sea ports along the Belt and Road (NDRC).

In the eyes of the Chinese people, the Belt and Road Initiative is an international strategy rather than a regional strategy, the goals of which are to coordinate an all-around opening of China to the world and promote further integration of the country into the global economy. With its economic interests spreading to every part 
of the world and facing a tighter external constraint, China is feeling the pressure to make a geo-strategic breakthrough and connect more with foreign countries. Its global strategy should be firstly deployed in Eurasia, which has long been the center of the world political area. The Belt and Road initiative has provided a geographic orientation for Chinese global strategy in the 21 st century but there are a lot of questions surrounding its conception and implementation. How will other countries treat the Belt and Road initiative of China and its global vision? What is the purpose of it? How will China carry it out and how will China explain and introduce it to the world China is?

\section{Literature Review}

The Belt and Road run through the rimland of southern Eurasia and the heartland of central Eurasia, connecting with many carefully chosen economically strategic points in this continent from east to west spatially. Its successful implementation will endow China with the ability to create a stronger strategic position in Eurasia, greatly improve China's external security environment and expand its interests and influence towards its borders (DU \& MA, 2015). Specific provinces and cities that belong to the Belt and Road initiative, especially Xinjiang province with lots of Muslims, Chongqing, Shanghai, Guangzhou and other areas close to Central Asia are still debating how they can best develop and obtain economic benefits and cultural exchanges from this initiative. Researcher Liu Xinlu holds the opinion that one important step to advance the Belt and Road initiative is to nurture common values: views of social development, international order, national interests and to assist with cultural exchanges, economic and trade cooperation and long-term mechanisms to solve conflicts. Considering the complex religious conditions across China and the rest of the world, Chinese religious expert Pei Yong proposes that, regardless of whether it is domestic or foreign work, everyone must pay close attention to the important religious issues. Irrespective of the Belt and Road initiative, religion plays an important role and sometimes even a decisive role in deciding matters (PEI, 2015). Mass communication is also used in the Belt and Road initiative. Chinese President Xi Jinping commands news agencies to broadcast stories that paint China in a good light. So Chinese news agencies discuss how to broadcast positive Belt and Road story to neighboring countries. The official news agency, Xin Hua news agency says that they can get an unexpectedly good social effect and a positive reception of the idea by telling stories and explaining the Belt and Road initiative. Xinhua news agency watches and listens closely to the remarks from foreign news agencies and think tanks and uses them as a reference point for new stories and/or understand foreign perception of the initiative (HUANG, 2015).

Regarding the impacts of the Belt and Road initiative for the world, Committee of Chinese Academy of Social Sciences, Zhang Yunling (2015) thinks the initiative matters peaceful rise of China. World economy suffered from financial crisis, and its recovery becomes sluggish, then China should shoulder the responsibility to think where the human being should go. At the macro level, it is also reasonable to believe that the concept and strategic path of the Belt and Road initiation makes it possible to realize 'community of human destiny'(Ming, 2015). This concept groups all of humanity together, working towards a single goal.

Outside of China, the discussion about the Belt and Road initiative does not always provide encouragement and support and typically there are more disputes than agreements. Yang Fuchang (2015) has reviewed the development of Sino-Arab relations in the past six decades. The Arab countries still doubt China's standpoint of respecting their national sovereignty and independence and continue to doubt whether China will be a reliable and contactable country under the Belt and Road Initiative. Whether Sino-Arab relations will thrive or 
fail. There are still some misunderstandings and questionings of the strategy. Al Shabiba, a newspaper based in Qatar questions who the real beneficiary from Belt and Road initiative is. Al-Jazeera writes that although President Xi Jinping stresses that the purpose of the Belt and Road initiative is to strengthen the relationship within China and its neighboring countries, there is no doubt that its final goals are to narrow the gaps between eastern China and western China. These indicate a lot of skepticism towards the real end-goal of the initiative and give China a lot of questions it needs to answer to satisfy these countries. The news equates Belt and Road initiative in China with the Greater East Asia Co-Prosperity project in Japan, merely less aggressive (CHEN \& $\mathrm{XU}, 2015)$. China is rethinking its own geopolitical layout and is eager to get rid of political pressures from the U.S. Judging from general strength and operability, the most creative area of China's diplomatic idea is its surrounding area. International public opinion often regards the Belt and Road initiative as Monroe Doctrine which aims to exclude outside intervention especially from the US (Sukjoon, 2014)

Is China using Belt and Road initiative as a counter to the Trans-Pacific Partnership Agreement (TPP)? Or is China challenging US and trying to remodel the rules of global economic structure and geopolitics? There are concerns and suspicions about the initiative.

\section{The Belt and Road Initiative in a Global Vision}

Handling the diplomatic relations with neighboring countries is going to be a key factor for the success of Belt and Road and persuading neighboring countries to relinquish parts of their own interests in this region and to balance domestic relationships is a challenging prospect. Implementation of Belt and Road is going to reconstruct regional interests and balance powers throughout the world.

Some countries near China are still thinking about if they will join the initiative or not. The three major powers around China are Russia, India, and Indonesia. Russia has shown great enthusiasm for it. India, however, has been reticent in its response and is still weighing up the benefits of joining such an initiative. Indonesia has tried to combine its "Global Maritime Axis" with the Belt and Road currently with little success. Southeast Asian countries value economic interests and strategic balance. They attach importance to economic cooperation with China but they are still vigilant towards China. South Asian countries pay particular attention to economic interests and national security, especially India. It treats China as a strong competitor. Relationships among China, Vietnam and the Philippines are increasingly unstable owing to territorial disputes involving the South China Sea.

Central Asia is a vastly complex area. Russia, USA, Europe, India, Iran, and Turkey all have underlying interests there and relations between countries need to be improved. Central Asia values economic development and security, they hope to get economic boons and expect China to play an active role in the security of the area, however, this is a situation that the US and Russia do not want to see, a strengthening of Chinese military power across Central Asia would certainly be seen as an aggressive move by them. Order of Eurasian continent is always related to the security and stability in the world (e.g., it is provenance of two World Wars, Westphalian system, Vienna System as well as Yalta system are all results of macroscopic struggle about Eurasian continent). After the cold war, there are at least twice reconstruction happened or happening in Eurasian continent, one is the disorganization of Soviet Union, the other will be the Belt and Road initiative in China, which will remodel the last mistake by Soviet Union (HU, 2015).

The construction plans and technical systems will include key passageways, junctions and projects aiming to build a unified coordination mechanism for whole-course transportation, increase connectivity between 
countries via new customs clearances and further develop multimodal transport between countries. This will gradually formulate compatible and standard transport rules that can be implemented for the benefit of global transport and trade.

The establishment of the Asian Infrastructure Investment Bank and BRICS New Development Bank are going to put Belt and Road into operation. In a broader view, AIIB is not only an economic bank, instead it is a political signal (ZHANG, 2015). The foundation of the Asian Infrastructure Investment Bank (AIIB) implies that the center of the world economy and politics power system is shifting.

China's foreign aid activities, which have been at a transitional stage, assistance change from multilateral institutions and organization for economic cooperation countries that are eager to share Chinese knowledge, with the expectation that China will eventually play a major role in international development (Naohiro, 2014). Chinese government remitted 260 million yuan debt of Zimbabwe, as a return, renminbi will be legal tender (dollar is also legal tender) in Zimbabwe. Zimbabwe is one example of renminbi becoming an international currency, since renminbi joins Special Drawing Right (SDR).

The Silk Road economic belt is regarded as the most important factor of China towards neighboring countries (first Central Asia). The clear objective is to strengthen economic cooperation between Europe and Asia and to build a new model of global governance. Of course, it is under the leadership of China, though it is denied by official propaganda.

At least for now, China and Russia are closely connected in the initiative. For Russia, its current relationships with both Ukraine and the US are not optimistic. As these relationships are currently strained, Russia can look towards China as a way to both maintain safety of its borders and as a way to guarantee continued development of its country. Appreciation of Ruble proves Russia with a strong ability to repair economy. Collaboration between China and Russia in Central Asia is mainly to go against the influence of the United States in the region. As neighboring countries become closely linked with China then China can more easily expand its security space. As long as China and Russia work together, the two powerful countries are able to promote and establish new international political and economic order, firstly within the Asia-Pacific area and Europe then reaching out towards the entire world. But it is very possible that India, Sri Lanka, and the Philippines might show a tougher hostility towards China and Russia. The possibility of India working with US cannot be excluded. If so the future situation in Asia won't be safer but become much more strained.

Weather the Belt and Road initiative will be successful and the new order of the world will be more reasonable are unknown for now, however, the power of countries will be changed for sure. Recognizing that America's future prosperity and security are very much intertwined with the prosperity and security of the East Asia-Pacific region, President Barack Obama has made a strategic commitment to rebalance American interests and investments within this region. As a response to China's rise, the United States is trying to rebalance interests and investments in the East Asian-Pacific area. The combination of alliance, military hegemony, economic containment and western isolation are being implemented to contain China in a full range (SHI, 2015). The U.S. government contributed to this narrative through its efforts to discourage allies from joining the new Asian Infrastructure Investment Bank (AIIB). In the end, major American allies such as the United Kingdom, Australia, and South Korea did join the Chinese initiative. Take UK for example, as Central Asia countries benefit economically from the infrastructure investment, Britain thinks it should be poised to take advantage. The long-term fundamentals of China's economy are strong that UK should keep faith with it. China has overtaken the United States as the world's leading trade power. As a measure, 123 countries in the world 
have China as their leading trading partner, while the US can count only 64 .

Considering some of its allies have already joined the AIIB, the situation for the United States is far from optimistic. The countries encompassed by the Belt and Road are also key areas for the United States. Asia-Pacific is not the only area where the post-war economic and financial leadership of the United States and its network of allies are being challenged. Beijing's ambitious plans to expand its influence throughout Asia by building desperately needed infrastructure are frequently reported by the Washington post. Xi Jinping's visit to the United States shows that he is keen to be seen as Obama's equal on the world stage. He is working behind the scenes to surpass the United States as Asia's regional power. Foreign investment and infrastructure construction are so fast and so furious.

The Belt and Road weakens the regional leadership of America both in regional security and international finance and the initiative makes allies of United States doubt if it is still the No. 1 power in the world or if China is going to replace it. Beijing is increasingly seen as a nuanced and aggressive actor, responding to regional needs (and its own), while Washington is playing defense, working to block new initiatives and seemingly struggling to keep pace with China (Ralph \& Brad, 2009). Working with Russia, the Belt and Road initiative has started to become reality. Tempted by economic benefit, some countries in Europe and Asia are possibly moving to support China, which makes the United States lose power in the world. Whether United States will ally with Southern Asia, Japan and other countries with close ties to America is unknown but the Belt and Road initiative will definitely affect the world's economical and geopolitical climate. Ultimately, opposition from the US and its allies would be internecine and peaceful resolution and compromise should be sought.

\section{Suggestions for the Belt and Road Initiative in the Vision of International Political Communication}

Director of the Shanghai Cooperation Organization Research Center, Chen Yurong proposes the Belt and Road initiative should be implemented in stages. The short-term goal is infrastructure; Medium-term objective is construction of Free Trade Zone in Central Asia; Long-term goal is building FTA groups include Central Asia, South Asia, West Asia, Europe, Africa and Latin America (about 100 countries in the world). It is the year just started the initiative and China is going to face lots of difficulties in the next 5 to 10 years. Not all the countries can be trading partners. It is not easy to promote sustainably the implementation of the Belt and Road initiative in consideration of the complexity of this strategy itself and the uncertainty of the current international environment and factors. It is necessary to realize the objectives of international political communication are different from that of internal country. Researchers in China pay too much attention on domestic research, but neglect the reality and reaction of neighboring countries to the Belt and Road initiative, the most important subject is, not all the neighboring countries prefer/ready to join it. More study on neighboring countries can provide true information about the initiate and suggestions on how to push forward it. Although Chinese have realized the religious, territorial issues, and so on, but the reality is more complicated than Chinese scholars and officials have imagined. And China's Industrial transfer and outward direct investment (ODI) are mainly to developing countries. Amount of ODI towards Belt and Road countries is $\$ 136.6$ hundred million, constituting $11.1 \%$ of all China's ODI (Statistical bulletin of Chinese Foreign Direct Investment, 2014) ${ }^{1}$. Most of the neighboring countries encompassed in the initiative are developing countries, which means they need more

\footnotetext{
${ }^{1}$ Statistical bulletin of Chinese foreign direct investment, 2014. Retrieved from http://www.stats.gov.cn/tjsj/.
} 
assistance and are undergoing more complicated social problems and unstable social environment.

Recent decades have seen the political area become more international, as the media have extend their reach, geographically and temporally. In the twenty first century media audiences are the targets of political communication not only from domestic sources, but foreign ones. Foreign governments, business organizations, and terrorists groups such as al-Quaida, all use the global information system to further their political objectives. Traditional forms of interpersonal international diplomacy persist, but modern wars, liberation struggles and territorial disputes are increasingly fought our in the media, with global public opinion as the prize (Mcnair, 2011) Chinese media agency realized the importance and urgency about developing their ability to broadcast Chinese voice and making plans to expand media industry though, they mainly rely on government support on finance and policy. In the end, it turns to be government propaganda rather than independent supervision organization on the government. As a result, most of the daily news about the Belt and Road initiative or international political communication are how welcome the initiative or the infrastructure is. The communication channels from overseas are blocked somehow. On the other side, generally speaking, all the strategic visions that have great impassion on international system will be blocked and refuted by western countries or news agency (Mcnair, 2011). No matter what the reason is for United States to compete with Belt and Road initiative, most American 23.scholars and news agencies attack it and it makes the initiative hard to carry out. After all, United States has the strongest news agency and government for now.

In the course of actualizing the Belt and Road concept, China's Non-Governmental Organizations (NOGS), as cornerstone of public diplomacy, must commit themselves to serving as messengers of people-to-people friendship, creating favorable public opinion in countries along the route, and undertaking the important task of introducing China to and establishing friendships with participating countries, so as to build the "Belt and Road" into "a route winning the hearts of the people" (WU, 2015). However, a research done by scholars is not optimistic about the communication. The research investigates the images of Belt and Road neighboring countries, and the result shows that Chinese do not know much about the neighboring countries; they show not positive, but ambiguous attitudes toward neighboring countries (K. ZHANG \& M. X. ZHANG, 2015). Though Chinese scholars and official institutions emphasize the importance of the initiative, Chinese non-governmental exchanges, tourism, study abroad programs are the adhesives of Belt and Road initiative. Without non-governmental organizations and exchanges, there is no point of the initiative. It is the interaction among citizens, civil society, and the state, communicating through the public sphere, those ensure the balance between stability and social change. Conduction of specific policy is maintained in public affairs. If citizens, civil society, or the state fail to fulfill the demands of this interaction, or if the channels of communication between two or more of the key components of the process are blocked, the whole system of representation and decision making comes to a stalemate (Manuel Castells, 2008).

\section{Conclusion}

The Belt and Road initiative proposed by China is a huge project. There are many practical difficulties in implementing it. The complex religious issues, social and economic contradictions are not able to be solved by China itself. As China puts forward human destiny community, it should realize how important cooperation among countries is. China, neighboring countries, regional powers, world powers will benefit from the initiative but also need help from each other. Compromise and confrontation are inevitable, because China is changing to be a super power in the world. 


\section{References}

CHEN, J., \& XU, P. Y. (2015). One Belt and One Road in the View of Arab Media-Taking into Account Chinese Media's Public Diplomacy to Arab States. Journal of Hui Muslim Minority Studies, 3, 119-125.

CHEN, Y. R. (2014). Opinions and suggestions from experts at home and abroad. Retrieved from http://jjsb.cet.com.cn/

China Daily. (2015). Renminbi is the legal tender in Zimbabwe. Retrieved from http://world.chinadaily.com.cn/guoji/2015-12/23/content_22787720.htm

DNRC. (2015). Vision and Actions on Jointly Building Silk Road Economic Belt and 21st-Century Maritime Silk Road. Retrieved from http://en.ndrc.gov.cn/newsrelease/201503/t20150330_669367.html

DU, D. B., \& MA, Y. H. (2015). One Belt and One Road: The grand geo-strategy of China's rise. Geographical Research, 34(6),1005-1014

HU, J. (2015). One belt and one road initiative and Remodeling of Eurasia. Contemporary World and Socialism, 2, 13-19.

HUANG, Y. (2015). How to report the Belt and Road initiative. International Communication, 4, 32-33

John Kemp. (2014). China's Silk Road challenges U.S. dominance in Asia. Retrieved from http://www.dailymail.co.uk/wires/reuters/article-2828579/Chinas-Silk-Road-challenges-U-S-dominance-Asia-Kemp.html

John Peace. (2015). China's new Silk Road to the West is an opportunity Britain must grasp. Retrieved from http://www.telegraph.co.uk/finance/china-business/11953922/Chinas-new-Silk-Road-to-the-West-is-an-opportunity-Britainmust-grasp.html

LIU, X. L. (2015). Nurturing the same values and constructing international voice in the background of the Belt and Road initiative. International Communication, 7, 51-53

Manuel Castells. (2008). The new public sphere: Global civil, society, communication, networks, and global governance. ANNALS, AAPSS.

Mcnair, B. (2011). An introduction to political communication (5th ed.). London: Routledge.

MING, H. (2015). The Belt and Road initiative with community of human destiny. Journal of Minzu University of China Philosophy and Social Sciences Edition, 6, 23-30

Naohiro, K. (2014). China's foreign aid at a transitional stage. Asian Economic Policy Review, 9(2), 301-317.

PEI, Y. (2015). Operating the power of religion on the Belt and Road initiative. Chinese Region, 6, 32-34

Peng, G. Q. (2015). The Belt and Road initiative and reconstruction of the order of the world. Retrieved from http://news.china.com.cn/live/2015-01/09/content_30754934.htm

Ralph, A. C., \& Brad, G. (2009). The United States and Asia-Pacific Region: Security strategy for Obama Administration. Center for New American Security.

SHI, Y. H. (2015). The Belt and Road initiative VS U.S. Asia-Pacific rebalance. World Knowledge, 11, 72.

Simon Denyer. (2015). The push and pull of China's Orbit. Washington Post.

Sukjoon, Y. (2014). Xi Jinping's "Monroe Doctrine": Rebuilding the Middle Kingdom Order?. Retrieved from http://www.eurasiareview.com/29052014-xi-jinpings-monroe-doctrine-rebuilding-middle-kingdom-order-analysis//

WU, X. J. (2015). Study on how to achieve the goal of the Belt and Road initiative in the international voice field. Journal of Fujian Communist Party School, 2, 97-103.

YANG, F. C. (2015). Invigorating Sino-Arab Relations by “One Belt and One Road” strategy. Arab World Studies, 5, 4-15.

ZHANG, K., \& ZHANG, M, X. (2015). Investigation Report on the Chinese People's Concept of the World. People's Forum.

ZHANG, W. M. (2015). The political significance of the "Belt and Road" Initiative and the Asian Infrastructure Investment Bank. China Review of Political Economy, 6(4), 204-224.

ZHANG, Y. L. (2015). Peaceful rising is the fundamental goal of the Belt and Road. Retrieved from http://shandongbusiness.gov.cn/public/html/news/201502/336641.html 